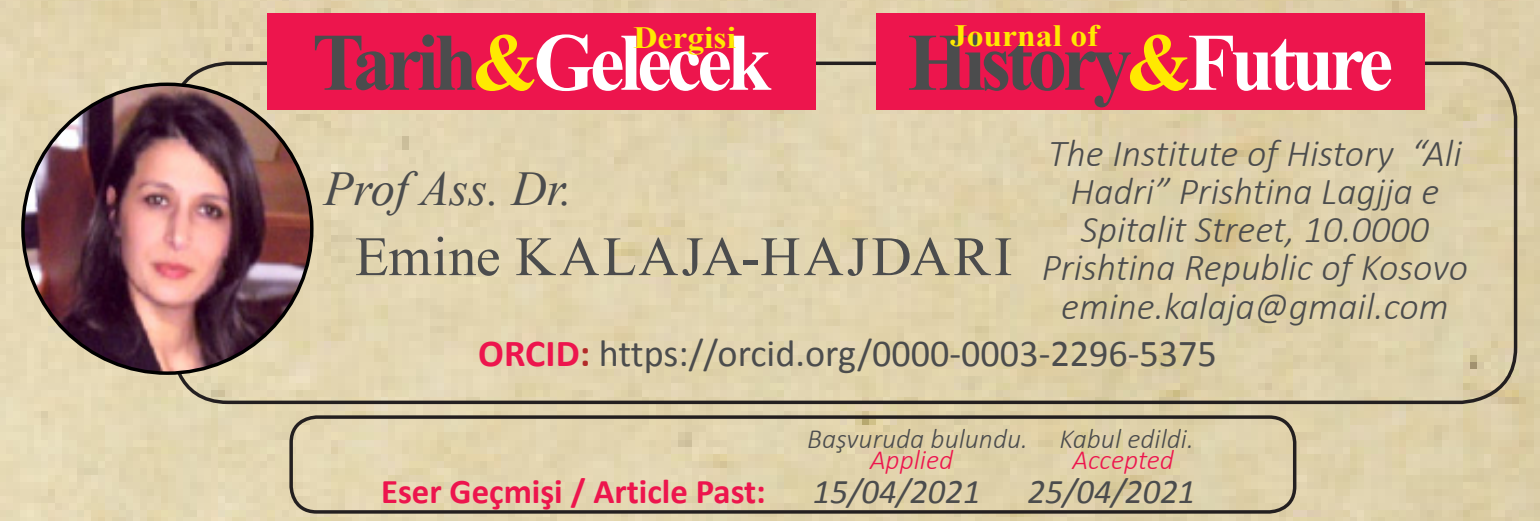

Araştırma Makalesi

DOI: http://dx.doi.org/10.21551/jhf.917202

Research Paper

Indexed by

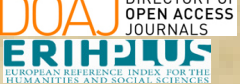

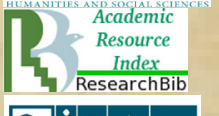

RISAM
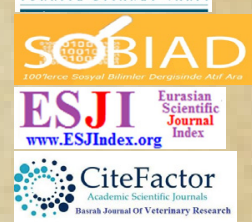

ideal

Orjinal Makale / Orginal Paper

\title{
Presence of the Oriental Community Evidenced by Epigraphic Monuments from Dardania
}

\section{Dardania Tarafindan Epigrafik Anitlardan Să̆lanan Doğu Topluluğunun Varlığı}

\section{Öz}

Dardania'nın Roma İmparatorluğu tarafindan fethi ve Romalıların idari, siyasi ve hukuki çerçevesine girmesinden sonra, Dardania bir dizi sosyo-politik, ekonomik ve kültürel değişim geçirdi. Bu değişikliklerin arka planına karşı, Dardania' da, epigrafik anıtlarda kanıtlanmış, çeşitli metalleri işleme konusunda askerler, albaylar, tüccarlar, köleler ve ustalar sıfatıyla gelen farklı toplulukların temsilcileri ortaya çıktı. Elverişli coğrafi konum ve Dardania'nın sahip olduğu sayısız doğal kaynak, siyasi ve ekonomik çıkarlarının Roma İmparatorluğu'nun bu bölümü ile doğu ya da batı vilayetlerinden gelen birçok Roma vatandaşı ile bağlantı kurmasını sağlar. Şimdiye kadar Dardania topraklarında keşfedilen epigrafik kaynakların sağladığı verilerden, Dardania topraklarında varlığı kanıtlanmış olan ve ordu ve tüccar temsilcilerinin yanı kentsel merkezlerde kamusal işlevlerin sahipleri olarak ayrıca sunulan doğu topluluğun varlığı öne çıkıyor.

Anahtar kelimeler: Dardania, doğu topluluğu, epigrafik anıtlar

\section{Abstract}

Upon the invasion of Dardania by the Romans and its inclusion in the administrative, political and judicial framework, the Dardanians became subject to a number of socio-political, economic and cultural changes. As part of such changes, representatives of various communities arrived in Dardania. The epigraphic monuments serve as evidence that the new migrants either had military background, or they came as colonizers, some were merchants, and there were even slaves and metal craftsmen. Considering Dardania's geographic position as well as its natural resources, it was only natural that foreign Roman citizens would settle in the province coming from both the eastern and western provinces. The epigraphic data found in Kosova, makes it clear that there was a presence of oriental communities who had settled throughout the territory of Dardania. Aside from serving in the military or being tradesmen, they also held public functions in urban centres.

Key words: Dardania, oriental community, epigraphic monuments 
The final invasion of central Balkan by the Romans by the end of the first century was manifested with many changes, which altered the core of political organization, socio-economic and cultural of the area's population. Part of these changes unavoidably became the Dardanians, who in ancient sources were known as a separate entity at least since the III-rd century B.C. In the administrative plan, Dardanian territory became part of Moesia, whereas when Moesia was divided in Moesia Superior in the west and Moesia Inferior in the east, in this case Dardania became a part of the administrative-legal frameworks of upper Moesia, and remained part of it until Diocletian, who in the framework of his radical reforms, transformed Dardania into a province in itself. In the economic plan, Dardania being a territory rich in mines, was organized early on as a separate fiscal territory, and this is best confirmed by the presence of Metalli Dardanici which represented an imperial mining complex. ${ }^{1}$

Special attention was paid to infrastructure and urbanization of this region, undertaking construction campaigns, and giving priority to building roads for military and economic needs. In parallel with the building of road infrastructure, the Romans started to conceptualise the creation of urban centres that followed Roman models, whose establishment was dictated by the gathering of craftsmen, merchants and practitioners of other professions around military camps, in order to serve the soldiers. These were known as civil settlements called canabea. The Romans constructed cities based on existing indigenous urban centres, through which they established their bases with the aim of Romanizing those centres later on, turning them into centres closer to the civiates. ${ }^{2}$ These centres later became the core of future municips, whose urban development took shape according to the Roman model.

It is well known that in Rome, day to day delivery of administrative power included a strong bureaucratic activity, which meant that at the level of the imperial chancellery there was a highly specialized staff. ${ }^{3}$ Thus the Romans, in parallel with the pacification of the territory, brought to the region several officials (apporitores) in order to exercise various bureaucratic functions related to the administration of the province, urban centres and economic activities, ${ }^{4}$ In these circumstances, representatives of various communities appeared in Dardania who had arrived in this province in the capacity of soldiers, settlers, merchants, slaves and metal workers. Such an action became possible due to the favourable geographic position of the province and the abundance of natural

1 Dušanić Slobodan 1977, "Aspects of Roman Mining in Noricum, Pannonia, Dalmatia and Moesia Superior", $A N R W$ II, 6/1977, (Berlin-New York, 1977; 1980), pp. 26-34.

2 Ćerškov, Emil, Romakët në Kosovë dhe Municipiumu DD te Soçanica, Prishtinë, (1973), 24.

3 Regarding the bureaucratic organization of the imperial administration see: CORIAT (1997), 249.

4 Among the apparitores, in the literature of the I - III centuries we encounter: scribae, lictores, viatores, praecones, accensi, nomenclatores, tabelarii, librarii, arcarii, interpretes, geruli, haruspices, medices, pullarii, victimarii, calatores, tibicines, fi dicines, fi ctores. Shih: Mommsen, Theodor, Le droit public romain I, Paris 1893, 380 sqq; RE 2 (1896) 191-194, s.v. apparitores (Hubel); Liebenam, Wilhelm, Städteverwaltung im römischen Kaiserreiche, Leipzig (1900), 276 sqq; Daremberg, Charles, Dictionnaire des antiquités grecques et romaines: d'après les textes et les monuments, Paris 18731919, vol. 1, p. 327-328, s.v. apparitores (G. Humbert); Langhamme, Walter, Die rechtliche und soziale Stellung der Magistratus Municipales und der Decuriones in der Übergangsphase der Städte von sich selbstverwaltenden Gemeinden zu Vollzugsorganen des spätantiken Zwangsstaates (2.-4. Jahrhundert der römischen Kaiserzeit), Wiesbaden (1973), 144 sqq; Neila, Rodríguez; Francisco, Juan, Apparitores y personal servil en la administración local de la Bética, (1997), 198 sqq. 
resources that Dardania possessed. Positioned in a crossroad between the east and west, as well as the Danube basin and the Mediterranean region, enabled the newer settlers to mingle with the communities that had settled there even before the Roman period.

The main source on which we will rely on to identify the presence of the different communities is the epigraphic material, considering that the results of archaeological excavations and written sources are but few. These monuments which are mainly erected by individuals of foreign origin, are mainly found in urban centres scattered in the geographical area of ethnic Dardania, which presents difficulties in dealing with this topic, since the material comes from a wide geographical territory.

From the data provided from epigraphic sources discovered so far in the territory of Dardania, in addition to the locals, Romanized locals and the many migrants who came either from the western or eastern provinces, who had linked their political and economic fate with this part to the Roman Empires, especially noteworthy is the presence of a community of Orientals. Their presence has been established throughout the territory of Dardania, who in addition to being representatives of the army and tradesmen also appear to have held public office in urban centres.

From the names presented in the inscriptions from the main administrative centre of Dardania, Scupi, which had the status of a colony, of particular interest for anthroponomy is the appearance of the oriental or Greek-speaking element, which is reflected in terms of their names and cognomens. Being a Roman colony, Scupi was inhabited by Roman citizens. Thus, the nucleus of veterans who were the founders of the colony in time expanded with the arrival of migrants from various regions of the empire, but also through the naturalization of the indigenous population. Through these waves, the Oriental or Greek-speaking community that we encounter through epigraphic sources was settled in Scupi. The influence of Greek culture from the south, respectively from Macedonia, was undoubtedly another driving factor that determined their settlement in this city.

From the names appearing in Scupi area, inscriptions that belong to the group of names of the oriental world, the only one who held high public office, that of decurio and dumvir, was the veteran $C$. Cornelius Magnus originating from Berytus (Syria). Berytus was a Roman colony founded in the time of Octavian August by veterans of legio V Macedonica and that of VIII Augusta. ${ }^{5}$ Among those who had marked their origin but who were not holders of public office are also Bassus originating from Antiochia, L. Cornelius originating from Methymeneus (Lesbos). ${ }^{6}$ From the inscriptions of monuments found in Scupi, we notice that a large number of them were freed men. Among them we also find those who belonged to the oriental community such as L. Cornelius, Marus Ellius Phobus, and then Ingenua who was most likely the daughter of a freed man. ${ }^{7}$ Members of the Oriental or Greek-speaking community most likely were also Antiocus, Euhelpis, both of these purely Greek cognomens. The first was widespread among the natives but also among slaves and freed men and was characteristic of the first century. ${ }^{8}$ Tyche, Hyperphanus and Hedyle also represent simple Greek cognomens characteristic for the II-III

5 Dragojevič-Josifovska, Borka, Inscriptions de la Mésie Supériore: Scupi et la Région de Kumanovo, vol. VI, CÉÉNFPHUB, Beograd, 1982, 45, pp. 77-78.

$6 \quad$ Ibid, no. 95, p.107, no. 187 , pp. 114-115.

7 Dragojevič-Josifovska, Borka, (1982), no. 187, no. 74, p. 95-96, p. 114-115, no. 111, pp. 116-117.

8 Mirdita, Zef, Antroponimia e Dardanisë në kohën romake, (Prishtinë, 1981), p. 63. 
century. These names presumably belonged to freed individuals, who were also part of the Greekspeaking community within the ethnic structure of the Scupi population. Aphrodisia (Latinized form of the Greek cognomen) should also be considered part of this community, followed by names such as Alexandro Epitynchanus, Xanthippus, Alexander, Eutychia, P. Aelius Menodotus, Valeria Lysimachei, L. Atilius Eucharistus, Fulcinio Evangelo, Pulcinia Hedyla etc., which were also simple Greek cognomens, and spreafad in the middle of the II-III century.

The presence of the oriental community within the heterogeneous population living in the Scupi colony is also reflected in the dedications to the gods, where in addition to honouring the gods of the Greco-Latin and indigenous cults, the oriental ones are also honoured. Among the oriental gods worshiped and revered among the population were Dea Syria, Serapis and Isis. ${ }^{10}$ Referring to the sign col. F. F. D. accompanying the dedication dedicated to Dea Syria, most likely a temple dedicated to her cult existed in the Scupi colony. ${ }^{11}$

In the ethnic structure of Ulpiana, the presence of citizens of oriental origin is also noted. For some of them it can be assumed that they were originally from Asia Minor. The spread of the cult of Jupiter Melano Cidiesso ${ }^{12}$ also speaks of a settlement of settlers from Asia Minor in Ulpiana. In the first two cases the common epithet is MEL, an attribute of Zeus Melano, who is presented as the protector of the Mela settlement in Bitini. The second epithet CID(iesso) is a latinized form and refers to Zeus Kidnessos, a city (Kideiessos) in Phrygia, a name which appears in the legends of the city's coins. ${ }^{13}$ Among his worshipers are members of the army, but also individuals with Latin

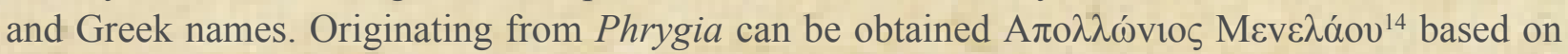
the altar dedicated to Zeus Ezaisko, where he is presented as a dedicator. Priests Victor Demetrius and Demetrius Ambibus ${ }^{15}$ were also of Eastern descent, probably Syrian. The votive altar in which these priests were presented was dedicated to Jupiter Dolichenus, a cult of Syrian origin. The fact that the veneration of his cult in Ulpiana was done by the priests Victor and Demetrius, leaves open the possibility of the presence of a temple dedicated to his cult in Ulpiana. ${ }^{16}$ This cult has been present until the III century. The Romanised M. Avrelius Octavius and Aelius Octavianus may also

9 On the spread of some of them as gentilice cf: Pape, Wilhelm, Wörterbuch der greichischen Eigennamen, Braunschëeig, (1911); on their presence in Dardania cf: Zef Mirdita, (1981 on their presence in Dalmaci cf: Alföldy, Géza, Die Personennamen in der römischen Provinz Dalmatia, Heidenberg, 1969.

10 Kalaja-Hajdari, Emine, "Dëshmitë epigrafike të pranisë së hyjnive të lindjes në Dardani", Kosova, 45, Instituti i Historisë, (Prishtinë, 2020), pp. 19-33

$11 \quad A E, 1984,0747$.

12 Ćerškov, Emil, Municipium DD kod Sočanice, ADJ, (Prishtinë-Beograd 1969), p. 65; Kalaja-Hajdari, Emine, Shndërrimet në Dardani gjatë periudhës romake, (Prishtinë, 2017), 308, p. 299; Peja, Fatmir, "Epigrafski Spomenici", Arheolosko Blago, (Beograd, 1998), p. 652; Kalaja-Hajdari, Emine, (2017), 280, pp. 301-302; Parovic-Pesikan, Maja, "Novi spomenik Jupitera Melana iz Ulpiani", AV41, (1990), p. 607; Kalaja-Hajdari, Emine, (2017), 321, p. 314; A. Hajdari, A. Buqinca "A New Unpublished Inscription Dedicated to Jupiter, Discovered in Ulpiana" Human and Social Studies 7 (3): 80-87 (2018).

13 Peja, Fatmir, "Jedan zanimlav natpis sa Ulpiane”, BMK XII-XIV, (Prishtinë, 1984), p. 59.

14 Móscy, Andras Gesellschaft und Romanisation in der romischen Provinz Moesia Superior, (BudapestAmsterdam, 1970), 244; L’Année épigraphique, (Paris, 1972), 144, 502; Mirdita, Zef, (1981), 247, p. 209; Kalaja-Hajdari, Emine, (2017), 266, p. 297.

15 Vulić, Nikola, “Antićki spomenici naše zemlje”, Spomenik LXXI, (1931), 192, 510; L’Année épigraphique, (Paris, 1966), p. 340; Mirdita, Zef, 1981, 248, p. 219; Kalaja-Hajdari, Emine, (2017), 277, p. 301.

16 Hajdari, Arben, Ulpiana et la romanisation de la Dardanie, (PhD Thesis), (Grenoble, Francë, 2013). 
be from Asia Minor. Both of them had erected altars dedicated to Jupiter Melano Cidieso. Based on their cognomens, names like M. Cocceius Eros,${ }^{17}$ Asclepiades Septimius, ${ }^{18}$ who held the post of vilicus, Asclepiades, ${ }^{19}$ Aurelius Asclepiades, ${ }^{20}$ Ulpius Ionicus, ${ }^{21}$ Alexandria,${ }^{22}$ Tatta, Idati Ablabius ${ }^{23}$ can also be considered as Orientals or Greek speaking. The fact that Tatta is an epichoric Greek name, ${ }^{24}$ while Ablabius is a characteristic name from Crete, ${ }^{25}$ and given that the builders of this monument possessed the status of a pilgrim, suggests that we are dealing with a family of migrants who came originally from Crete.

Even in the city of Naisuss there were a number of Greek-speaking migrants, whose origin is difficult to determine due to lack of data. Aside from one individual who held a high public office, the rest are mostly slaves, some free men and some soldiers. From the servants we distinguish servus vilicus Philoxenus Augustrum, who served in the stations Aquarum Ba. While Nica and Hermes $^{26}$ were released, most likely imperial released, while Hermogenes and Nicias, released by veteran $C$. Iulio Vindici. ${ }^{27}$ Among the Roman citizens who bore names characteristic of the Greek-speaking population, we distinguish Posidonius ${ }^{28}$ decurio in the municipality of Naissus, then Plato, ${ }^{29}$ soldier of the cohors of Cilicum.

Citizens of Oriental origin and from the Greek-speaking world have also played an important role in the DD Municipium. Unlike other centres where the municipal aristocracy consisted mainly of colonists from Italy and other western provinces, in the DD municipium the Orientalists and Greek settlers played an essential role in the political and economic life of the city. Among them,

17 Dragojevič-Josifovska, Borka, (1982), 104, p. 118; Premerstein-Vulić, "Antike Denkmalerin Serbien und Macedonien”, 213 JÖAI VI, (Wien, 1903), Bb. 31, 37; Vulić, Nikola, (1931),195, p. 519; Mirdita, Zef, (1981), 248, p. 124; Kalaja-Hajdari, Emine, (2017), 265, p. 265.

18 Shukriu, Edi, "Dea e Dardanisë dhe monumentet tjera epigrafike nga Smira", BFF 26, (Prishtinë, 2001), p. 27; Kalaja-Hajdari, Emine, (2017), 285, p. 303.

19 Parović-Pešikan, Maja, "Novi spomenik Jupitera Melana iz Ulpiani”, $A V$ 41, (1990), p. 607; KalajaHajdari, Emine, (2017), 321, p. 314.

20 Corpus Inscriptionum Latinarum, III, Berlin, 8180; Evans, Arthur J. Antiquarien researches in Ilyricum, Archeologia, (London, 1885), p. 60; Jahreschefte der Österreichischen Archäologischen Instituts, Wien, Bb.33, 41; Mirdita, Zef, (1981), 252-253, p. 243; Kalaja-Hajdari, Emine, 2017, 311, p. 311.

21 CIL III, 8177; Evans, Arthur J. (1885), p. 74; Mirdita, Zef, (1981), 246, p. 206; Kalaja-Hajdari, Emine, (2017), 258, p. 295.

22 Mirdita, Zef, "Novitates Epigraphikae e Dardania Collectae", $A V$ XXXI, (1980), 190, p. 9; KalajaHajdari, Emine, (2017), 303, p. 309.

23 Mirdita, Zef, “O jednoj ari is centralnog podrucja Dardanije”, AV 38, (1987), p. 363-368; Dobruna-Salihu, Exhlale Plastika dekorative dhe figurative e gurit në Dardani gjatë kohës romake, IAP, (Prishtinë 2005), 824, p. 336; Kalaja-Hajdari, Emine, 2017, 319, p. 314.

24 Hajdari, Arben, (2013), p. 206.

25 Latinas, Thesaurus Linguae. Thesaurus linguae Latinate 1. (Teubner 1900), 120.

26 Petrovć, Petar, Inscriptions de la Mési Superiore, Naissus-RemesianaHorreum Marg, vol. IV, (Beograd, 1979), nr. 6, p. 70.

27 CIL III, 1682; Petrovć, Petar, (1979), nr. 37, p. 85; Mirdita Zef, (1981), 271, p. 361; Kalaja-Hajdari, Emine, (2017), 334, p. 319.

28 Petrović, Petar, (1979), 72, p. 10; Mirdita, Zef, (198)1, 278, p. 407; Kalaja-Hajdari, Emine, 2017, 384, p. 333.

29 JÖAI, 1900, Bb. 128; CIL III, 8250; Petrovć, Petar, 1979, 83, p. 33; Kalaja-Hajdari, Emine, 2017, 339, p. 321. 
a number of freedmen stand out. From the knights we have M. Aurelius Asclepiades ${ }^{30}$ who was a veteran, then Titeno Vero ${ }^{31}$ procurator metallorum. As Orientals or Greek speakers who appear as carriers of high functions, we can also distinct names such as Novelius Eros ${ }^{32}$ procurator imperatoris, Menander ${ }^{33}$ centurio officiarum. Members of this community probably were Herculano, Aelia Hesperia, ${ }^{34}$ Telesphorus, ${ }^{35}$ Eros Mae, Voconia Epicaris, ${ }^{36}$ whose status in absence of epigraphic data is not known. The role and presence of oriental community in Municipium DD confirms also the worship of Antonio's cult, who was represented as Antinoo Heroi. ${ }^{37}$ In honour of his cult, habitants of Municipium DD also build a temple, which represents the only temple of Antinoi discovered in the Balkans. ${ }^{38}$

Aside from those found in known urban areas, there are also a number of oriental or Greek names found in epitaphs outside of urban centres. Among them we distinguish Ulpius Atticus, Ulpius Thalasus, ${ }^{39}$ Aelius Maurus,${ }^{40}$ Aelius Niceforus, ${ }^{41}$ Tiberius Surus, ${ }^{42}$ names which come from the region of Dukagjini plain. We also encounter names such as Abascantus, Achilleus, Apollonides, Pomphorus, Hercla, Zoie, Publicia Callirhoe, ${ }^{43}$ who seem to have been either slaves or freed man (libertinus).

Although there is a lack of epigraphic data and there are only a small number of names that we can determine are of oriental origin, it is also difficult to link names to ethnic origins, given they are a result of specific circumstances. On the other hand, the presence of oriental cults serves as an additional argument that there were indeed oriental settlers who lived in Dardania under Roman occupation. Indeed, it was through cults and toponymic epithets from their place of origin, as is the case with Zeus Ezzaios and Melano Cidieso, that they were able to express clearly their ethic and cultural identity.

Because of its natural resources, especially metals, Dardania was of particular interest to the Roman Empire ever since the second century AD. Several notable Romans tied their interests to Dardania, who served there either as military, merchants, craftsmen etc. Migrations from the

30 Ćerškov, Emil, 1970, 65, p. 14; Mirdita, Zef, 1981, 269, p. 349; Kalaja-Hajdari, Emine, 2017, 564, p. 387.

31 Ćerškov, Emil, 1969, 64, p. 11; Mirdita, Zef, 1981, 269, p. 347; Kalaja-Hajdari, Emine, 2017, 562, p. 386.

32 Ćerškov, Emil, 1970, 65, p. 13; Mirdita, Zef, 1981, 269, p. 348; Kalaja-Hajdari, Emine, 2017, 563, p. 387.

33 CIL III, 14606; JÖAI 3, 1900, Bb. 166, 66; Ćerškov, Emil, 1969, 68, p. 28; Mirdita, Zef, 1981, 265, p. 318; Kalaja-Hajdari, Emine, 2017, 521, p. 376.

34 Vulić, Nikola, 1941-1948, "Antički spomenici naše zemlje", Spomenik SKA 98, p. 225; Ćerškov, Emil, 1969, 63, p. 9; Mirdita, Zef, 1981, 266, p. 330, 382; Kalaja-Hajdari, Emine, 2017, 543, p. 381. Ćerškov, Emil, 1969, 62, p. 4; Mirdita, Zef, 1981, 266, p. 327; Kalaja-Hajdari, Emine, 2017, 381, p. 540. CIL III, 8296; Ćerškov, Emil, 1969, 68, p. 29; Mirdita, Zef, 1981, 263, p. 309; Kajala-Hajdari, Emine, 2017, 511, p. 373.

$37 A E, 1972,143$, p. 500, Kalaja-Hajdari, Emine, 2017, 544, p. 382.

38 Regarding the representation of Antinoi cult in Upper Moesia cf: Šašel Kos, Marjeta, "Antinous in Upper Moesia-The introduction of a new cult." Opinione pubblica e forme di comunicazione a Roma: il linguaggio dell'epigrafia, 2009.

39 Mirdita, Zef, 1981, 259, p. 283; Kalaja-Hajdari, Emine, 2017, 599, p. 397.

40 Vulić, Nikola, 1931, 277; Mirdita, Zef, 1981, 260, p. 293; Kalaja-Hajdari, Emine 2017, 610, p. 400.

41 Vulić, Nikola 1931, 273; Mirdita, Zef 1981, 260, p. 292; Kalaja-Hajdari, Emine, 2017, 609, p. 400.

42 Mirdita, Zef, 1981, pp. 135-136.

43 Dragojevič-Josifovska, Borka, 1982, no. 222, 208, 209, 212, 225. 
eastern provinces must have been part of the same population movements. When it comes to migration, if we refer to epigraphic data, the first wave of migrations occurred in the second part of first century, which grew even broader in the second one, a time period that corresponds with the increasing economic importance of Dardania, especially in mining. It was during this time that the oriental communities started appearing in the territory. In addition to being part of the military, slaves, craftsmen or merchants, their presence should be seen as serving the function of the growing mining, which grew took a more important role upon Roman invasion. It seems that the local population could not meet the Roman expectations in mining, so they decided to bring in mining experts from the eastern provinces, who were well experienced in the trade. The best example of this is the concentration of such communities in the vicinity of mining locations in Ulpiana and Municip DD.

\section{Bibliography:}

Alföldy, Géza, Die Personennamen in der römischen Provinz Dalmatia, Heidenberg, 1969.

Ćerškov, Emil, Municipium DD kod Sočanice, ADJ, Prishtinë-Beograd 1969.

Ćerškov, Emil, Romakët në Kosovë dhe Municipiumu DD te Soçanica, Prishtinë, 1973.

Corpus Inscriptionum Latinarum, III, Berlin, 8180;

Daremberg, Charles, Dictionnaire des antiquités grecques et romaines : d'après les textes et les monuments, Paris 1873-1919, vol. 1.

Dobruna-Salihu, Exhlale, Plastika dekorative dhe fgurative e gurit në Dardani gjatë kohës romake, IAP, Prishtinë 2005.

Dragojevič-Josifovska, Borka, Inscriptions de la Mésie Supériore: Scupi et la Région de Kumanovo, vol. VI, CÉÉNFPHUB, Beograd, 1982.

Dušanić, Slobodan, 1977a, “Aspects of Roman Mining in Noricum, Pannonia, Dalmatia and Moesia Superior”, $A N R W$ II, 6/1977, Berlin-New York, 1977.

Evans, Arthur J. Antiquarien researches in Ilyricum, Archeologia, London, 1885.

Ferri, Naser, Monumentet ushtarake të periudhës romake në Mezi të Epërme, Pejë 2001.

Hajdari, Arben, Ulpiana et la romanisation de la Dardanie, (thèse de doctorat), Grenoble, Francë, 2013.

Hajdari, Arben, Buqinca, Arianit, "A New Unpublished Inscription Dedicated to Jupiter, Discovered in Ulpiana" Human and Social Studies 7 (3), 2018.

Kajanto, Iiro, The latine cognomen, 1965.

Kalaja-Hajdari, Emine, "Dëshmitë epigrafike të pranisë së hyjnive të lindjes në Dardani”, Kosova, 45, Instituti i Historisë, Prishtinë, 2020.

Kalaja-Hajdari, Emine, Shndërrimet në Dardani gjatë periudhës romake, Prishtinë, 2017.

L'Année épigraphique, Paris, 1972.

Langhamme, Walter r, Die rechtliche und soziale Stellung der Magistratus Municipales 
und der Decuriones in der Übergangsphase der Städte von sich selbstverwaltenden Gemeinden zu Vollzugsorganen des spätantiken Zwangsstaates (2.-4. Jahrhundert der römischen Kaiserzeit), Wiesbaden 1973.

Liebenam, Wilhelm, Städteverwaltung im römischen Kaiserreiche, Leipzig (1900).

Mirdita, Zef, "Novitates Epigraphikae e Dardania Collectae”, AVXXXI, 1980.

Mirdita, Zef, “O jednoj ari is centralnog podrucja Dardanije”, AV 38, 1987.

Mirdita, Zef, Antroponimia e Dardanisë në kohën romake, Prishtinë, 1981

Mommsen, Theodor, Le droit public romain I, Paris 1893, 380 sqq; RE 2 (1896).

Móscy, Andras, Gesellschaft und Romanisation in der romischen Provinz Moesia Superior, Budapest-Amsterdam, 1970.

Neila, Rodríguez; Francisco, Juan, Apparitores y personal servil en la administración local de la Bética, 1997.

Pape, Wilhelm, Wörterbuch der greichischen Eigennamen, Braunschëeig, 1911.

Parovic-Pesikan, Maja, "Novi spomenik Jupitera Melana iz Ulpiani”, AV41, 1990.

Peja, Fatmir, "Epigrafski Spomenici”, Arheolosko Blago, Beograd, 1998.

Peja, Fatmir, “Jedan zanimlav natpis sa Ulpiane”, BMK XII-XIV, Prishtinë, 1984.

Petrovć, Petar, Inscriptions de la Mési Superiore, Naissus-Remesiana Horreum Marg, vol. IV, Beograd, 1979.

Premerstein-Vulić, “Antike Denkmalerin Serbien und Macedonien”, 213 JÖAI VI, Wien, 1903.

Shukriu, Edi, "Dea e Dardanisë dhe monumentet tjera epigrafike nga Smira”, BFF 26, 2001.

Šašel Kos, Marjeta, "Antinous in Upper Moesia-The introduction of a new cult." Opinione pubblica e forme di comunicazione a Roma: il linguaggio dell'epigrafia, 2009.

Thesaurus Linguae Latinae 1, 1900.

Vulić, Nikola, 1941-1948, ”Antički spomenici naše zemlje”, Spomenik SKA.

Vulić, Nikola, “Antićki spomenici naše zemlje”, Spomenik LXXI, 1931. 